\section{Multiple Middle Meningeal Artery Aneurysms Associated with Fistulous Galenic Arteriovenous Malformation: A Case Report}

\author{
Fistülöz Galen Arteriovenöz \\ Malformasyonu ile Birlikteliği Olan Çoğul \\ Orta Meningeal Arter Anevrizmaları: \\ Bir Olgu Sunumu
}

\begin{abstract}
Non-traumatic multiple saccular aneurysms of the middle meningeal artery are extremely rare lesions. In our case the patient was a 51-year-old woman admitted with complaints of progressive headache. Magnetic resonance imaging showed a dilatation of the vein of galen malformation. Cerebral angiography revealed multiple saccular aneurysms of the middle meningeal artery and fistulous type of galenic arteriovenous malformation. Only one case of non-traumatic multiple middle meningeal artery aneurysms has been reported until now and this case of multiple multiple middle meningeal artery aneurysms associated with the fistulous type of galenic arteriovenous malformation is unique.
\end{abstract}
KEYWORDS:
Aneurysm,
Middle
meningeal artery,
Arteriovenous malformation

ÖZ

Travmatik olmayan çoklu sakküler orta meningeal arter anevrizmaları oldukça nadir lezyonlardır. Olgumuz 51 yaşında bayan baş ağrısı ile başvurmuştur. Manyetik resonans görüntülemede galen veni malformasyonunun dilate veni görülmüştür. Serebral anjiografide fistülöz tip galen veni arteriovenöz malformasyonu ve çoklu orta meningeal arter anevrizması saptanmıştır. Literatürde daha önce travmatik olmayan, çoklu orta menningeal arter anevrizmalı yalnızca bir olgu rapor edilmiş olup, bu olgumuz fistülöz tip galen veni arteriovenöz malformasyonu ile birlikteliği olan tek olgudur.

ANAHTAR SÖZCÜKLER: Anevrizma, Orta meningeal arter, Arteriovenöz malformasyon

\section{Mahmut AKYUZ \\ Recai TUNCER}

Akdeniz University, School of Medicine, Department of Neurosurgery, Antalya, Turkey

Received : 06.08.2009

Accepted : 31.08 .2009

Correspondence address: Mahmut AKYUZ Akdeniz University, Medical School, Department of Neurosurgery, Dumlupınar Bulvarı, Kampus Alanı, 07059 Antalya, Turkey

E-mail : mahmutakyuz@akdeniz.edu.tr 


\section{INTRODUCTION}

Aneurysms of the middle meningeal artery are extremely rare. Thirty traumatic aneurysms of the middle meningeal artery (MMA) have been reported in the literature. Non-traumatic aneurysms of the MMA are again extremely rare lesions and only 17 cases of non-traumatic MMA aneurysms have been reported (1-17). They may present as any type of intracranial hemorrhage or be discovered incidentally $(5,7,13)$. Almost all cases found in the literature were associated with increased hemodynamic stresses caused by a variety of associated intracranial pathological conditions. We report a unique case of a non-traumatic multiple MMA aneurysms that was associated with a fistulous type of galenic AVM.

\section{CASE REPORT}

A 51-year-old woman complained of headache and discomfort for about 1 year. The neurological examination was normal and did not reveal papiledema or other clinical signs of raised intracranial pressure. The axial T2-weighted magnetic resonance imaging revealed a dilatation of the vein of galen malformation (Figure 1). Cerebral angiography showed two saccular aneurysms arising from the MMA and the transmesencephalic fistulous type of galenic AVM (Figure 2, 3).

Endovascular treatment was recommended for the fistulous type of galenic AVM, and multiple aneurysms of the MMA.

\section{DISCUSSION}

Saccular aneurysms of meningeal vessels are extremely rare in comparison with the frequency of cerebral aneurysms. Occasional notice of these aneurysms has been reported by several authors, more often after head trauma. However, to our knowledge only 17 cases of non-traumatic MMA aneurysms have been reported (1-17). Most of the cases involved patients in whom cranial blood flow had increased demands placed on it as a result of pathological conditions. Three cases were associated with Paget's disease $(1,8,9)$. There were four cases associated with vascular malformation (two dural angiomas, one cavernous hemangioma, and one moyamoya disease) $(4,10,12,14)$. One case was associated with occlusion of the posterior cerebral artery, and another with occlusion of the internal carotid artery (15-16). Two cases were reported in two women with a convexity meningioma and a pterional

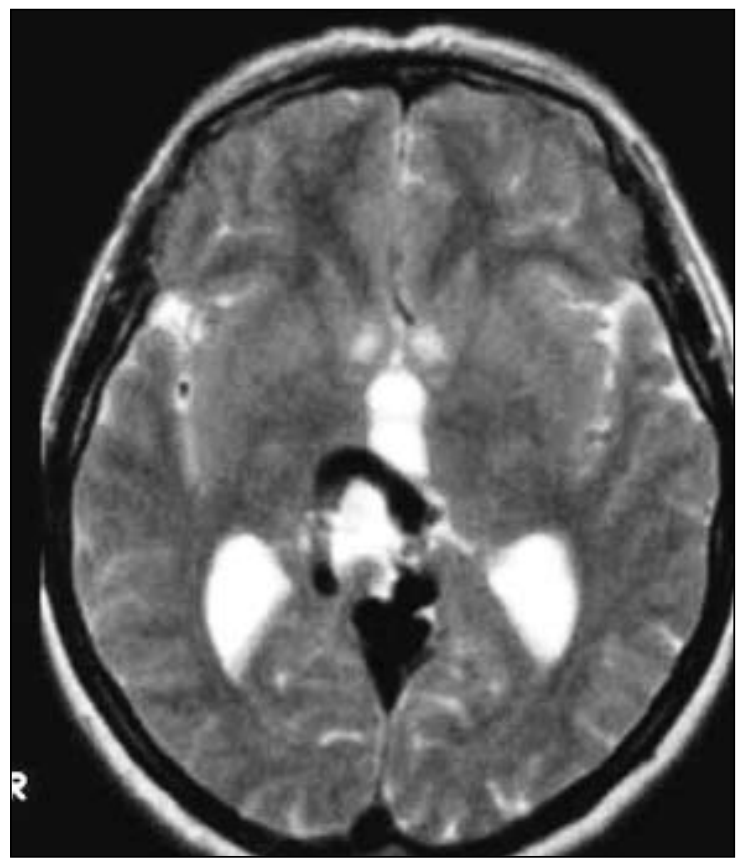

Figure 1: The axial T2-weighted magnetic resonance imaging showed dilatation of vein of galen malformation.

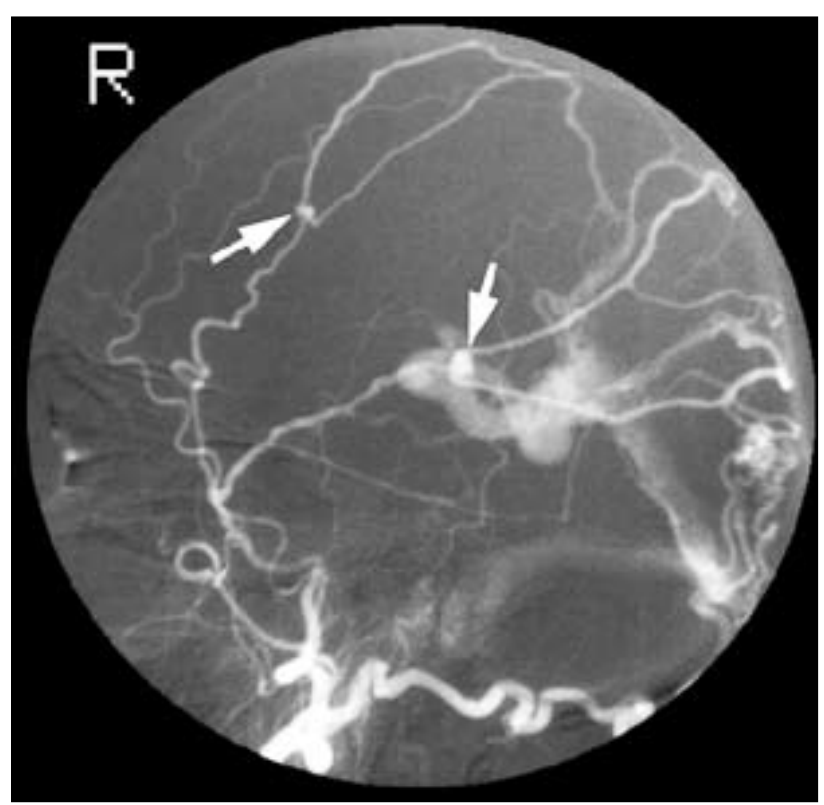

Figure 2: External carotid angiography demonstrating two saccular aneurysms arising from MMA and dilatation of vein of galen.

meningioma $(7,11)$. Eleven of the 17 cases reportedly have been associated with significant hemodynamic stresses and our case is associated with fistulous type of galenic AVM. This AVM would generate enough hemodynamic stress on the external carotid flow to be possibly responsible for these aneurysms. The 


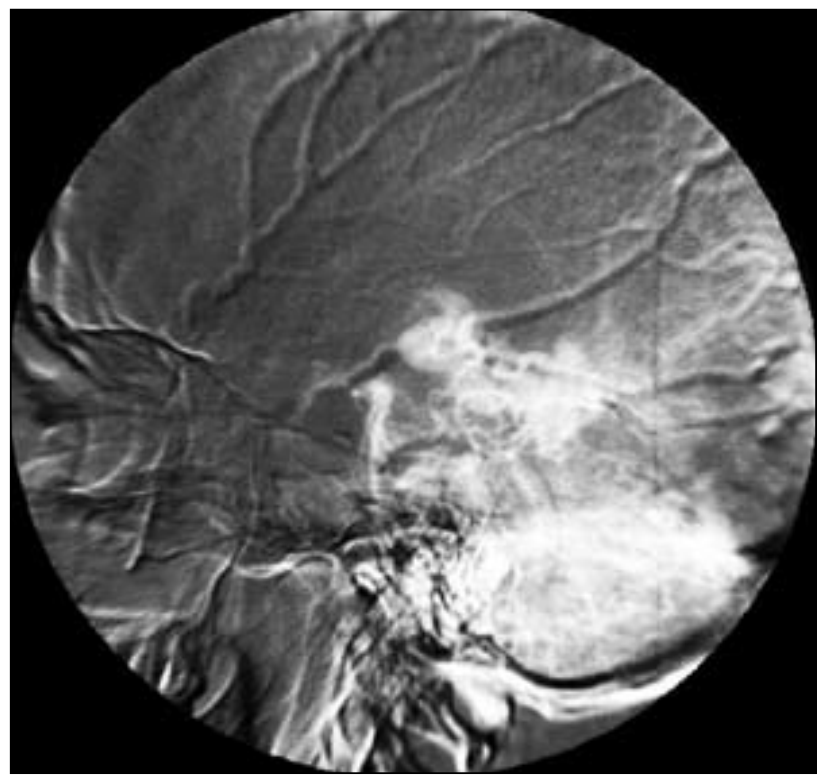

Figure 3: Cerebral angiography demonstrating transmesencephalic fistulous connection between posterior cerebral artery branches and the vein of galen.

association AVM of galen and multiple aneurysms of MMA has not been reported till now in literature.

This pathological entity, although rare, can be devastating. Aneurysms of the MMA have presented with subdural hemorrhage, epidural hemorrhage and intraparenchymal hemorrhage or these aneurysms have been discovered in the unruptured state in association with various pathological condition. The small number of non-traumatic aneurysms of the MMA makes it impossible to predict natural history of this lesion. There are reports where aneurysms of nontraumatic-MMA have been treated surgically. In our case, we recommended endovascular treatment for the fistulous type of galenic AVM and multiple MMA aneurysms, because surgical treatment of the galen region AVMs is associated with a high morbidity and mortality. Reports of endovascular treatment of galenic AVM in the literature approach the disease from a purely technical viewpoint and often fail to provide satisfactory mid-term results. Focusing the therapeutic challenge on a strictly morphological goal overlooks the fundamental aspects of neonatal, infant and adult anatomy and fluid physiology.

\section{CONCLUSION}

Non-traumatic MMA aneurysm should be kept in mind in patients with a vascular malformation while interpreting angiograms and during preoperative therapeutic planning. External carotid angiography should be performed in patients with a vascular malformation.

\section{REFERENCES}

1. Berk ME: Aneurysm of the middle meningeal artery. Br J Radiol 34:667-668, 1961

2. Bollati A, Galli G, Gandolfini M, et al: True aneurysm of the middle meningeal artery. Case report. J Neurosurg Sci 24: 89-92, 1980

3. Holland HW, Thomson JLG: Aneurysm of middle meningeal artery. Clin Radiol 16:334-338, 1965

4. Jin KH, Toyoda S, Kumagai, et al: Non-traumatic middle meningeal aneurysm and angioma in a child. Brain Dev 3: 323-328, 1981

5. Korosue $\mathrm{K}$, Kondoh $\mathrm{T}$, Ishikawa $\mathrm{Y}$, et al: Acute subdural hematoma associated with nontraumatic middle meningeal artery aneurysm:case report. Neurosurgery 22:411-413, 1988

6. Kobata H, Tanaka H, Tada Y, Nishihara K, Fujiwara A, Kuroiwa $\mathrm{T}$ : Intracerebral hematoma due to ruptured nontraumatic middle meningeal artery aneurysm-case report. NeuroMed Chir 41(12):611-614, 2001

7. Lama M, Mottolese C: Middle meningeal artery aneurysm associated with meningioma. J Neurosurg Sci 44(1):39-41, 2000

8. New PFJ: True aneurysm of the middle meningeal artery. Clin Radiol 16:236-240, 1965

9. New PFJ: True aneurysm of the middle meningeal artery, cranial Paget's disease and hypertension: A triad. Clin Radiol 18:154-157, 1967

10. Ohta $\mathrm{H}$, Tanazawa $\mathrm{T}$, Osuka $\mathrm{K}$, et al: True aneurysm of the middle meningeal artery associated with cavernous hemangioma of the skull-case report: Neurol Med Chir 31: 203-205,1991

11. O'Neill OR, Barnwell SL, Silver DJ: Middle meningeal artery aneurysm associated with meningioma: Case report. Neurosurgery 36:396-398,1995

12. Sanchis JF, Orozco M, Cabanes J: Spontaneous extradural hematomas. J Neurol Neurosurg Psychiatry 38:577-580, 1975

13. Sandin JA III, Salamat S, Başkaya M, Dempsey RJ: Intracerebral hemorrhage caused by the rupture of a nontraumatic middle meningeal artery aneurysm. J Neurosurg 90:951-954, 1999

14. Takahashi M: Magnification angiography of cerebral aneurysms associated with moyamoya disease. AJNR 1: 547-550, 1980

15. Ushikoshi S, Houkin K, Itoh F, et al: Ruptured aneurysm of the middle meningeal artery associated with occlusion of the posterior cerebral artery. Case report. J Neurosurg 84: 269-271,1996

16. Zingesser LH, Schechter MM, Rayport M: Truths and untruths concerning the angiograhic finding in extracerebral haematomas. Br J Radiol 38:835-847, 1965

17. Zubkov YN, Matsko DE, Pak VA: Saccular aneurysms of meningeal artery: Case report. Neurosurgery 42:664-666, 1998 